\title{
Crystal Structure and Characterization of a New Eight Coordinated Cadmium Complex
}

\author{
Mohammad Hakimi*, Keyvan Moeini, Zahra Mardani, and Farzaneh Khorrami \\ Chemistry Department, Payame Noor University, 19395-4697 Tehran, I.R. Iran. \\ "E-mail:mohakimi@yahoo.com
}

(Received May 14, 2013; Accepted May 25, 2013)

\begin{abstract}
In this work, a new cadmium complex $\left[\mathrm{Cd}(\mathrm{L})\left(\mathrm{CH}_{3} \mathrm{COO}\right)_{2}\right] \cdot 2 \mathrm{H}_{2} \mathrm{O}(\mathbf{1})$ with the ligand $\mathrm{L}, N, N^{\prime}$-bis $(2$-pyridinecarboxalidene)-1,2-cyclohexanediamine was prepared and identified by elemental analysis, FT-IR, Raman, ${ }^{1} \mathrm{H}$ NMR spectroscopy and single-crystal X-ray diffraction. The cadmium atom in the crystal structure of $\mathbf{1}$ has distorted triangular dodecahedral geometry by coordination of the four nitrogen atoms of $\mathrm{L}$ and four oxygen atoms of the two acetate ions. Two water molecules are also incorporated in the crystal network. The $\mathrm{O}-\mathrm{H} \cdots \mathrm{O}$ hydrogen bonds present in the crystal structure of $\mathbf{1}$. In this work, three structural surveys including coordination numbers of the cadmium atom, coordination modes of $\mathrm{L}$ and resonance in pyridine2-ylmethanimine-based compounds are presented.
\end{abstract}

Key words: Triangulated dodecahedral geometry, Cadmium complex, Spectral characterization, X-ray crystal structure

\section{INTRODUCTION}

Schiff bases are an important class of ligands that coordinate to metal ions via the azomethine nitrogen and have been studied extensively for their important properties, e.g. their ability to reversibly bind oxygen, ${ }^{1}$ transfer of an amino group, ${ }^{2}$ photochromic properties, ${ }^{3}$ catalytic activity in the hydrogenation of olefins. ${ }^{4}$ Also many Schiff base complexes show catalytic activity in various reactions at high temperature and in the presence of moisture. ${ }^{5,6}$ Schiff bases show strong complexing ability towards some toxic metals ${ }^{7}$ and diverse biological activities, such as antibacterial and antitumor. 8,9

In this work the preparation and characterization of the cadmium(II) complex, $\left[\mathrm{Cd}(\mathrm{L})\left(\mathrm{CH}_{3} \mathrm{COO}\right)_{2}\right] \cdot 2 \mathrm{H}_{2} \mathrm{O}$ (1) with

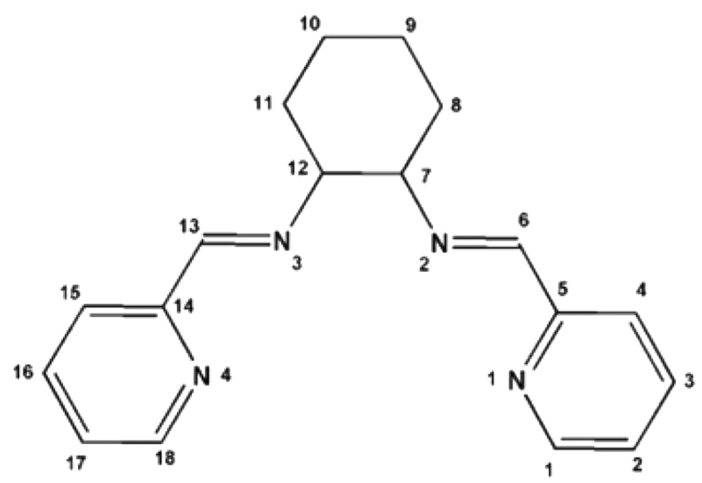

Scheme 1. The structure of L, this numbering scheme used for the ${ }^{1} \mathrm{H}$ NMR spectrum assignments.
$N, N$ '-bis(2-pyridinecarboxalidene)-1,2-cyclohexanediamine (L, Scheme 1) is described.

The coordination geometry of the cadmium atom and the nature of the ligands afford the coordination numbers of the cadmium atom in range of $2-10 .{ }^{10}$ In this paper we endeavor to introduce coordination aspects of the tetradentate ligand with cadmium atom.

\section{EXPERIMENTAL}

All chemicals and solvents were reagent or analytical grade and used as received. The ligand $\mathrm{L}$ was prepared according to the literature. ${ }^{11}$ The carbon, hydrogen, and nitrogen contents were determined in a Thermo Finnigan Flash Elemental Analyzer 1112 EA. The infrared spectrum as $\mathrm{KBr}$ pellet was recorded in the range of 400-4000 $\mathrm{cm}^{-1}$ using a FT-IR 8400-Shimadzu spectrometer. The Raman spectrum was obtained using a Nicolet Model 910 Fourier-transform spectrometer. Melting point was determined using a Barnsted Electrothermal 9200 electrically heated apparatus. ${ }^{1} \mathrm{H}$ NMR spectrum was recorded on a Bruker Aspect 3000 instrument operating at $250 \mathrm{MHz}$; chemical shifts are given in parts per million, with values in reference to an internal standard of TMS.

\section{Synthesis of $\left[\mathrm{Cd}(\mathrm{L})\left(\mathrm{CH}_{3} \mathrm{COO}\right)_{2}\right] .2 \mathrm{H}_{2} \mathrm{O},(1)$}

$\mathrm{Cd}\left(\mathrm{CH}_{3} \mathrm{COO}\right)_{2} .2 \mathrm{H}_{2} \mathrm{O}(1 \mathrm{mmol}, 0.26 \mathrm{~g})$ was dissolved in $\mathrm{EtOH}(10 \mathrm{~mL})$ and added with stirring to a solution of L (1 $\mathrm{mmol}, 0.29 \mathrm{~g})$ in EtOH $(10 \mathrm{~mL})$. The reaction mixture was 
stirred at $60{ }^{\circ} \mathrm{C}$ for $2 \mathrm{~h}$. Colorless crystals suitable for X-ray diffraction were obtained from the solution after standing for few days. Colorless crystals (47\%), m.p. $209^{\circ} \mathrm{C}$; Anal. Calc. for $\mathrm{C}_{22} \mathrm{H}_{30} \mathrm{CdN}_{4} \mathrm{O}_{6}(558.90)$ : C, 47.28; $\mathrm{H}, 5.41 ; \mathrm{N}$, 10.02. found: $\mathrm{C}, 46.93 ; \mathrm{H}, 5.45 ; \mathrm{N}, 9.93 \%$; IR ( $\mathrm{KBr}$ disk): $3472\left(v_{a s} \mathrm{H}_{2} \mathrm{O}\right), 3293\left(v_{\mathrm{s}} \mathrm{H}_{2} \mathrm{O}\right), 3058\left(v \mathrm{CH}_{\text {imine }}\right.$ and/or $\left.\mathrm{CH}_{\mathrm{ar}}\right), 3016\left(v \mathrm{CH}_{\text {imine }}\right.$ and/or $\left.\mathrm{CH}_{\mathrm{ar}}\right), 2932\left(v \mathrm{CH}_{2}\right), 1659$ ( $v$ $\mathrm{C}=\mathrm{N}_{\text {imine }}$ and $/$ or $\left.\delta \mathrm{H}_{2} \mathrm{O}\right), 1581\left(\nu \mathrm{C}=\mathrm{N}_{\mathrm{py}}\right), 1558\left(v_{a s} \mathrm{COO}\right)$, $1475\left(v_{s} \mathrm{COO}\right.$ and/or $\left.v \mathrm{C}=\mathrm{C}\right), 1419\left(\delta_{\text {as }} \mathrm{CH}_{2}\right), 1342\left(\delta_{\mathrm{s}}\right.$ $\left.\mathrm{CH}_{2}\right), 1149(v \mathrm{C}-\mathrm{N}), 779$ and $663(\gamma$ py and/or $\delta$ OCO), 625 $\left(\rho_{\mathrm{r}} \mathrm{H}_{2} \mathrm{O}\right), 584\left(\rho_{\mathrm{w}} \mathrm{H}_{2} \mathrm{O}\right) \mathrm{cm}^{-1}$. Raman: $3019\left(v \mathrm{CH}_{\text {imine }}\right.$ and/or $\left.\mathrm{CH}_{\mathrm{ar}}\right), 2901\left(v \mathrm{CH}_{2}\right), 1634\left(v \mathrm{C}=\mathrm{N}_{\text {imine }}\right.$ and/or $\left.\delta \mathrm{H}_{2} \mathrm{O}\right)$, $1511\left(v \mathrm{C}=\mathrm{N}_{\text {py }}\right.$ and/or $\left.\mathrm{C}=\mathrm{C}\right), 1391\left(\delta_{\text {as }} \mathrm{CH}_{2}\right), 1150(v \mathrm{C}-\mathrm{N})$, 804 and $649\left(\gamma\right.$ py and/or $\left.\rho_{\mathrm{r}} \mathrm{H}_{2} \mathrm{O}\right), 494(v \mathrm{Cd}-\mathrm{N}), 369(v$ $\mathrm{Cd}-\mathrm{O}), 246\left(\rho_{\mathrm{t}} \mathrm{H}_{2} \mathrm{O}\right) .{ }^{1} \mathrm{H}$ NMR $\left(250 \mathrm{MHz},\left[\mathrm{D}_{6}\right] \mathrm{DMSO}\right)$ : $\delta=1.6-2.1\left(\mathrm{~m}, 8 \mathrm{H}, \mathrm{C}^{8} \mathrm{H}_{2}-\mathrm{C}^{11} \mathrm{H}_{2}\right) ; 3.5\left(\mathrm{~d}, 2 \mathrm{H}, \mathrm{C}^{7} \mathrm{H}, \mathrm{C}^{12} \mathrm{H}\right)$; 4.1 (s, $\left.3 \mathrm{H}, \mathrm{CH}_{3} \mathrm{COO}^{-}\right)$; 7.5-8.1 (m, $4 \mathrm{H}, \mathrm{C}^{2} \mathrm{H}, \mathrm{C}^{3} \mathrm{H}, \mathrm{C}^{16} \mathrm{H}$, $\left.\mathrm{C}^{17} \mathrm{H}\right) ; 8.4$ (s, $\left.2 \mathrm{H}, \mathrm{C}^{6} \mathrm{H}, \mathrm{C}^{13} \mathrm{H}\right) ; 8.9-8.6$ (d, $2 \mathrm{H}, \mathrm{C}^{4} \mathrm{H}$, $\left.\mathrm{C}^{15} \mathrm{H}\right) ; 8.7-8.8\left(\mathrm{~d}, 2 \mathrm{H}, \mathrm{C}^{1} \mathrm{H}, \mathrm{C}^{18} \mathrm{H}\right)$.

\section{Crystal Structure Determination and Refinement}

A suitable crystal of $\mathbf{1}$ was placed on an Oxford Diffraction Gemini Ultra diffractometer and kept at $150.0 \mathrm{~K}$ during data collection. Using Olex-II, ${ }^{12}$ the structure was determined with the Shelxs ${ }^{13}$ structure solution program using Direct Methods and refined with the Shelx ${ }^{13}$ refinement package using least-squares minimization.

CCDC 870105 for $\left[\mathrm{Cd}(\mathrm{L})\left(\mathrm{CH}_{3} \mathrm{COO}\right)_{2}\right] .2 \mathrm{H}_{2} \mathrm{O}(\mathbf{1})$ contain the supplementary crystallographic data for this paper. These data can be obtained free of charge from The Cambridge Crystallographic Data Centre via www.ccdc.cam. ac.uk/data_request/cif.

\section{RESULTS AND DISCUSSION}

\section{Synthesis and Spectroscopic Characterization}

A study using CSD data for complexes of $L$ showed that complex 1 is the first example of a complex with a $\mathrm{CdN}_{4} \mathrm{O}_{4}$ environment in which $\mathrm{N}_{4}$ and $\mathrm{O}_{4}$ belong to a tetradentate ligand and two acetate groups, respectively.
This study also showed that complexes of $\mathrm{Mn},{ }^{14} \mathrm{Pr}, \mathrm{Sm},{ }^{15}$ $\mathrm{Cu},{ }^{16} \mathrm{Gd}, \mathrm{Ce}, \mathrm{Yb}, \mathrm{Nd}, \mathrm{Er},{ }^{17} \mathrm{Pt},{ }^{18} \mathrm{Mo},{ }^{19} \mathrm{Ag},{ }^{20}$ and $\mathrm{Pd}^{21}$ with $\mathrm{L}$ were reported previously. All coordination modes of $\mathrm{L}$ are presented in Table 1. Among these modes, the three chelate form which was observed in $\mathbf{1}$ is most frequent.

Reaction between $\mathrm{L}$ and aqueous solution of cadmium (II) acetate in a molar ratio of 1:1 gave 1 which was characterized by IR, Raman, ${ }^{1} \mathrm{H}$ NMR spectroscopy and X-ray crystallography. This complex is air-stable and soluble in DMSO and DMF.

In the IR spectra of $\mathbf{1}$ and L, there are two bands near 1650 and $1600 \mathrm{~cm}^{-1}$ which were assigned to the vibrations of the $v\left(\mathrm{C}=\mathrm{N}_{\text {imine }}\right)$ and $v\left(\mathrm{C}=\mathrm{N}_{\mathrm{py}}\right)$ respectively. The $v$ $\left(\mathrm{C}=\mathrm{N}_{\text {imine }}\right)$ in the IR spectrum of 1 shifted $16 \mathrm{~cm}^{-1}$ to higher energy indicating coordination through the nitrogen atom.

Three bands at 1558, 1475 and $663 \mathrm{~cm}^{-1}$ which were assigned to the $v_{\text {as }}(\mathrm{COO}), v_{\mathrm{s}}(\mathrm{COO})$ and $\delta(\mathrm{OCO})$ respectively, confirmed the presence of acetate ion in $\mathbf{1}$. The differences between asymmetric $\left(v_{\mathrm{as}}\right)$ and symmetric $\left(v_{\mathrm{s}}\right)$ stretching of the acetate group $(\Delta)$ can reveal its coordination type. The $\Delta$ value for acetate salt is $164 \mathrm{~cm}^{-1}$. In unidentate complexes, $\Delta$ values are much greater than the acetate salt while in bidentate complexes these values are significantly less than the acetate salt. ${ }^{22 \mathrm{a}}$ The $\Delta$ value for $\mathbf{1}$ is $83 \mathrm{~cm}^{-1}$, thus acetate ion here acts as a bidentate ligand. The presence of a water molecule in $\mathbf{1}$ affects the IR and Raman spectra in three regions including $3200-3550 \mathrm{~cm}^{-1}$ for asymmetric and symmetric $\mathrm{OH}$ stretches, 1600-1630 $\mathrm{cm}^{-1}$ for $\mathrm{H}_{2} \mathrm{O}$ bending and $200-600 \mathrm{~cm}^{-1}$ for "librational modes". These modes are due to rotational oscillations of the water molecules restricted by interactions with neighboring atoms and they are classified into three types (wagging $\left(\rho_{\mathrm{w}}\right)$, twisting $\left(\rho_{\mathrm{t}}\right)$ and rocking $\left(\rho_{\mathrm{r}}\right)$ ) depending upon the direction of the principal axis of rotation. ${ }^{2 b, 23} \mathrm{We}$ assigned all types of the vibrations for $\mathrm{H}_{2} \mathrm{O}$ molecules in the IR and Raman spectra of $\mathbf{1}$ but vibrations such as $\delta$ $\left(\mathrm{H}_{2} \mathrm{O}\right), v(\mathrm{C}=\mathrm{C})$ and $\gamma($ py) overlapped with vibrations due to $v\left(\mathrm{C}=\mathrm{N}_{\text {imine }}\right), v_{\mathrm{s}}(\mathrm{COO})$ and $\delta(\mathrm{OCO})$, respectively.

Information about the low-frequency vibrations of metal-

Table 1. Different types of coordination modes of L collected by CSD

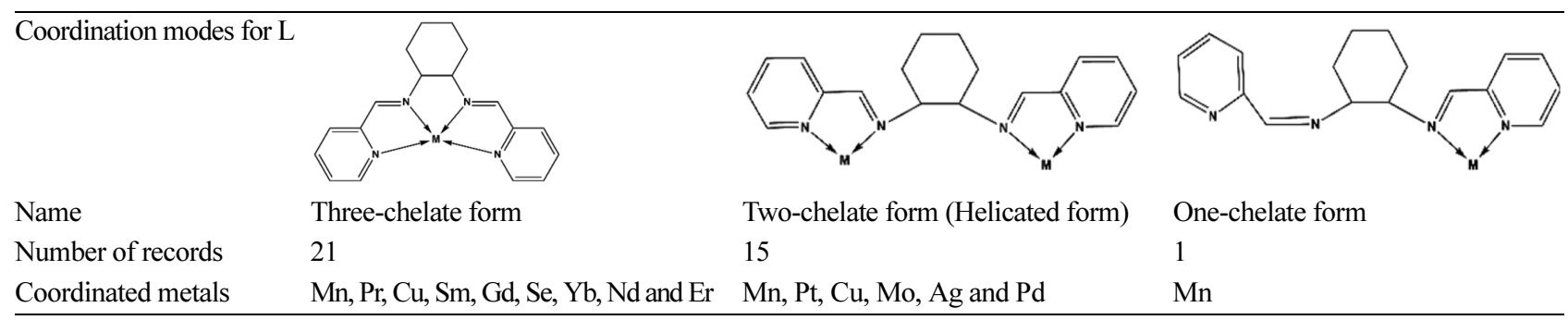


ligand bonds can be obtained by Raman spectroscopy. ${ }^{24} \mathrm{In}$ the Raman spectrum of $\mathbf{1}$, two bands at 494 and $369 \mathrm{~cm}^{-1}$ were assigned to the $v(\mathrm{Cd}-\mathrm{N})^{25}$ and $v(\mathrm{Cd}-\mathrm{O})^{26}$ respectively. Attention to the $\mathrm{Cd}-\mathrm{N}$ and $\mathrm{Cd}-\mathrm{O}$ bond lengths confirms the higher stretching vibration of the $\mathrm{Cd}-\mathrm{N}$ bond in respect to the $\mathrm{Cd}-\mathrm{O}$ bond.

The numbering scheme used for the ${ }^{1} \mathrm{H}$ NMR spectrum of $\mathbf{1}$ is given in Scheme 1. In the ${ }^{1} \mathrm{H}$ NMR spectrum of $\mathrm{L},{ }^{11}$ the signal at $8.3 \mathrm{ppm}$ was assigned to the $\mathrm{C}^{6} \mathrm{H}$ proton. After coordination to $\mathbf{1}$, the $\mathrm{C}^{6} \mathrm{H}$ signal is shifted by 0.1 ppm to lower field.

Table 2. Crystal data and structure refinement for $\left[\mathrm{Cd}(\mathrm{L})\left(\mathrm{CH}_{3} \mathrm{COO}\right)_{2}\right]$. $2 \mathrm{H}_{2} \mathrm{O}$

\begin{tabular}{|c|c|}
\hline Empirical formula & $\mathrm{C}_{22} \mathrm{H}_{30} \mathrm{CdN}_{4} \mathrm{O}_{6}$ \\
\hline Formula weight, $\mathrm{g} \mathrm{mol}^{-1}$ & 558.90 \\
\hline Crystal size, $\mathrm{mm}^{3}$ & $0.11 \times 0.08 \times 0.03$ \\
\hline Temperature, $\mathrm{K}$ & 150 \\
\hline Crystal system & triclinic \\
\hline Space group & $P-1$ \\
\hline \multicolumn{2}{|l|}{ Unit cell dimensions } \\
\hline$a, \AA$ & $8.5520(3)$ \\
\hline$b, \AA$ & $11.2524(4)$ \\
\hline$c, \AA$ & $13.0219(5)$ \\
\hline$\alpha,{ }^{\circ}$ & $87.639(3)$ \\
\hline$\beta,{ }^{\circ}$ & $76.893(3)$ \\
\hline$\gamma,{ }^{o}$ & $77.716(3)$ \\
\hline Volume, $\AA^{3}$ & 1192.49 \\
\hline $\mathrm{Z}$ & 2 \\
\hline Calculated density, $\mathrm{g} \mathrm{cm}^{-3}$ & 1.56 \\
\hline Absorption coefficient, $\mathrm{mm}^{-1}$ & 0.9 \\
\hline$F(000), \mathrm{e}$ & 572 \\
\hline$\theta$ range for data collection (deg) & $2.9-29.3$ \\
\hline$h, k, l$ ranges & $\begin{array}{l}-11 \leq h \leq 11,-14 \leq k \leq 15, \\
-16 \leq l \leq 17\end{array}$ \\
\hline Reflections collected / independent $/ R_{\text {int }}$ & $9501 / 5539 / 0.0278$ \\
\hline Data / ref. parameters & $5539 / 306$ \\
\hline Goodness-of-fit on $F^{2}$ & 1.061 \\
\hline$R 1 / w R 2(I \geq 2 \sigma(I))$ & $0.0490 / 0.1070$ \\
\hline$R 1 / w R 2$ (all data) & $0.0612 / 0.1137$ \\
\hline Largest diff. peak / hole, e $\AA^{-3}$ & $1.13 /-0.72$ \\
\hline
\end{tabular}

\section{Description of the Crystal Structure}

The crystal structure of $\left[\mathrm{Cd}(\mathrm{L})\left(\mathrm{CH}_{3} \mathrm{COO}\right)_{2}\right] \cdot 2 \mathrm{H}_{2} \mathrm{O}(\mathbf{1})$ has been determined by single-crystal $\mathrm{X}$-ray diffraction analysis. Diagrams of the molecular structure and unit cell were created using Ortep-III, ${ }^{27}$ Mercury ${ }^{28}$ and Diamond. ${ }^{29}$ Crystallographic data and details of the data collection and structure refinement are listed in Table 2. Selected bond lengths and angles for complex are listed in Table 3 and hydrogen bond geometries are presented in Table 4.

In the crystal structure of $\mathbf{1}$ (Fig. 1), the cadmium atom is coordinated by two imine and two pyridine nitrogen atoms of $\mathrm{L}$ and four oxygen atoms of the two acetate ions in distorted triangular dodecahedral geometry (Fig. 2).

The bond length averages of the two $\mathrm{Cd}-\mathrm{N}_{\text {imine }}$ and two $\mathrm{Cd}-\mathrm{N}_{\mathrm{py}}$ bonds are 2.404 and $2.432 \AA$ respectively, which are larger than those of CSD average (2.307 and $2.354 \AA$ for $\mathrm{Cd}-\mathrm{N}_{\mathrm{imine}}$ and $\mathrm{Cd}-\mathrm{N}_{\mathrm{py}}$, respectively). In the crystal structure of $\mathbf{1}$, the cyclohexane ring has a chair conformation and two chiral centers on the $\mathrm{C} 7$ and $\mathrm{C} 12$ with the same enantiomeric forms. The unit cell of $\mathbf{1}$ contains two complexes with a racemic mixture of the $R, R$ and $S, S$ isomers. In complex 1 the bond length of $\mathrm{C} 6=\mathrm{N} 2$ imine $(1.253(6) \AA)$ is shorter than the $\mathrm{C}=\mathrm{N}_{\mathrm{py}}(1.336(5)$ and $1.340(6) \AA$ for $\mathrm{C} 1=\mathrm{N} 1$ and $\mathrm{C} 5=\mathrm{N} 1$, respectively) and comparable to isolated imine bond lengths in the literature. ${ }^{30}$ This means that probably there is no resonance or very weak resonance between the pyridine ring and imine group in this structure. The average of all 6-substituted imine bonds in pyridine-2-ylmetha-

Table 3. Selected bond length $(\AA)$ and angles $\left({ }^{\circ}\right)$ for $[\mathrm{Cd}(\mathrm{L})$ $\left.\left(\mathrm{CH}_{3} \mathrm{COO}\right)_{2}\right] \cdot 2 \mathrm{H}_{2} \mathrm{O}$ with estimated standard deviations in parentheses

\begin{tabular}{llll}
\hline \multicolumn{3}{c}{ Bond lengths } & \multicolumn{2}{c}{ Angles } \\
\hline $\mathrm{Cd}(1)-\mathrm{N}(1)$ & $2.436(3)$ & $\mathrm{N}(1)-\mathrm{Cd}(1)-\mathrm{N}(2)$ & $67.9(1)$ \\
$\mathrm{Cd}(1)-\mathrm{N}(2)$ & $2.398(3)$ & $\mathrm{N}(2)-\mathrm{Cd}(1)-\mathrm{N}(3)$ & $67.6(1)$ \\
$\mathrm{Cd}(1)-\mathrm{N}(3)$ & $2.411(3)$ & $\mathrm{N}(3)-\mathrm{Cd}(1)-\mathrm{N}(4)$ & $67.5(1)$ \\
$\mathrm{Cd}(1)-\mathrm{N}(4)$ & $2.428(3)$ & $\mathrm{N}(1)-\mathrm{Cd}(1)-\mathrm{O}(1)$ & $91.1(1)$ \\
$\mathrm{Cd}(1)-\mathrm{O}(1)$ & $2.455(4)$ & $\mathrm{N}(2)-\mathrm{Cd}(1)-\mathrm{O}(1)$ & $82.3(1)$ \\
$\mathrm{Cd}(1)-\mathrm{O}(2)$ & $2.439(4)$ & $\mathrm{N}(3)-\mathrm{Cd}(1)-\mathrm{O}(1)$ & $93.1(1)$ \\
$\mathrm{Cd}(1)-\mathrm{O}(3)$ & $2.464(3)$ & $\mathrm{N}(4)-\mathrm{Cd}(1)-\mathrm{O}(1)$ & $88.9(1)$ \\
$\mathrm{Cd}(1)-\mathrm{O}(4)$ & $2.469(4)$ & $\mathrm{O}(1)-\mathrm{Cd}(1)-\mathrm{O}(2)$ & $53.0(1)$ \\
\hline
\end{tabular}

Table 4. Hydrogen bond geometries $\left(\AA,{ }^{\circ}\right)$ for $\left[\mathrm{Cd}(\mathrm{L})\left(\mathrm{CH}_{3} \mathrm{COO}\right)_{2}\right] .2 \mathrm{H}_{2} \mathrm{O}$

\begin{tabular}{cccccc}
\hline $\mathrm{D}-\mathrm{H} \cdots \mathrm{A}$ & $d(\mathrm{D}-\mathrm{H})$ & $d(\mathrm{H} \cdots \mathrm{A})$ & $<(\mathrm{DHA})$ & $d(\mathrm{D} \cdots \mathrm{A})$ & Symmetry code on $\mathrm{A}$ atom \\
\hline $\mathrm{O}(5)-\mathrm{H}(5 \mathrm{~A}) \cdots \mathrm{O}(2)$ & 0.851 & 1.936 & 163.7 & $2.763(5)$ & $x, y, z$ \\
$\mathrm{O}(5)-\mathrm{H}(5 \mathrm{~A}) \cdots \mathrm{O}(3)$ & 0.851 & 2.583 & 94.7 & $2.786(6)$ & $x, y, z$ \\
$\mathrm{O}(5)-\mathrm{H}(5 \mathrm{~B}) \cdots \mathrm{O}(2)$ & 0.850 & 2.687 & 86.1 & $2.763(5)$ & $x, y, z$ \\
$\mathrm{O}(5)-\mathrm{H}(5 \mathrm{~B}) \cdots \mathrm{O}(3)$ & 0.850 & 1.945 & 170.0 & $2.786(6)$ & $x, y, z$ \\
$\mathrm{O}(6)-\mathrm{H}(6 \mathrm{~A}) \cdots \mathrm{O}(1)$ & 0.849 & 1.992 & 175.8 & $2.840(5)$ & $1+x, y, z$ \\
$\mathrm{O}(6)-\mathrm{H}(6 \mathrm{~B}) \cdots \mathrm{O}(4)$ & 0.851 & 1.922 & 173.4 & $2.768(6)$ & $x, y, z$ \\
\hline
\end{tabular}




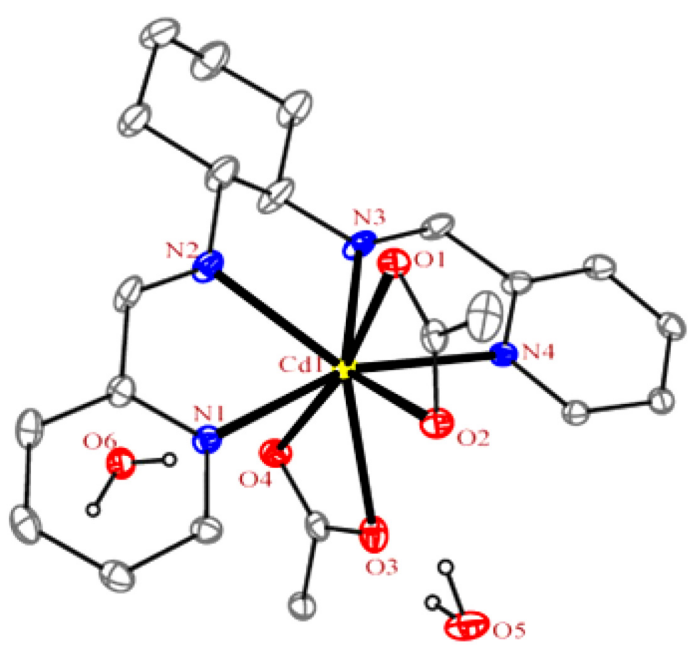

Figure 1. The Ortep-III diagram of the molecular structure of $\mathbf{1 .}$ The displacement ellipsoids are drawn at the $20 \%$ probability level. The hydrogen atoms of ligand were omitted for clarity.

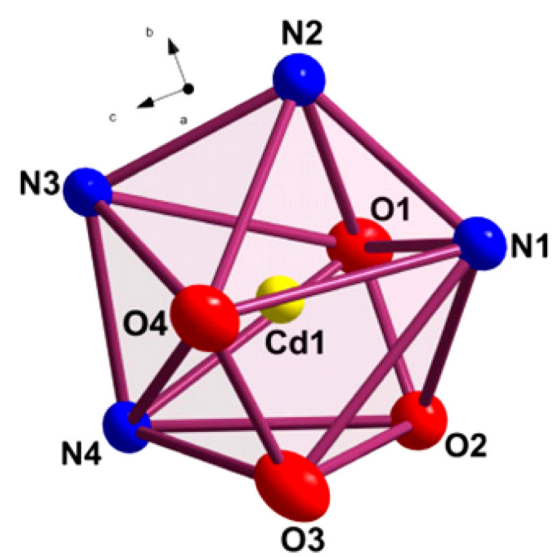

Figure 2. Distorted triangulated dodecahedral geometry around the cadmium atom in $\mathbf{1}$.

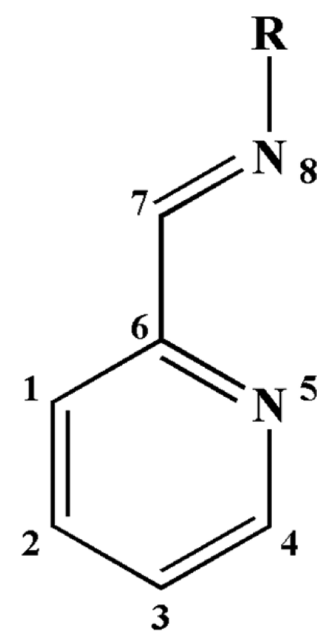

Scheme 2. The base was used for study of imine bond lengths in CSD.

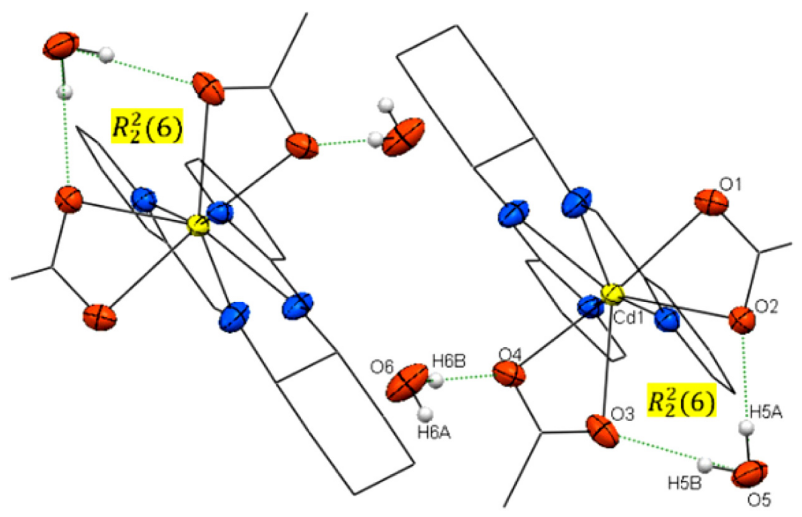

Figure 3. Packing of 1 , showing $\mathrm{R}_{2}^{2}(6)$ hydrogen bond motifs and $\mathrm{C}\left(s p^{3}\right)-\mathrm{H} \cdots \pi, \mathrm{O}-\mathrm{H} \cdots \mathrm{O}$ hydrogen bonds. Only the hydrogen atoms involved in hydrogen bonds are shown.

nimine-based structures (Scheme 2) is $1.264 \AA$ (calculated by $\left.\mathrm{Vista}^{31}\right)$ that confirms this result.

In the crystal packing of $\mathbf{1}$ (Fig. 3), two oxygen atoms of each acetate group coordinate to cadmium atom and at the same time form a $\mathrm{R}_{2}^{2}(6)$ motif ${ }^{32,33}$ by $\mathrm{O}(5)-\mathrm{H}(5 \mathrm{~A}) \cdots \mathrm{O} 2$ and $\mathrm{O}(5)-\mathrm{H}(5 \mathrm{~B}) \cdots \mathrm{O} 3$ strong hydrogen bonds ${ }^{34}$ with the water molecule. The other water molecule acts as hydrogen bond bridge and connects two coordinated acetate groups in adjacent complexes by $\mathrm{O}(6)-\mathrm{H}(6 \mathrm{~A}) \cdots \mathrm{O} 1$ and $\mathrm{O}(6)-$ $\mathrm{H}(6 \mathrm{~B}) \cdots \mathrm{O} 4$ hydrogen bonds. The $\mathrm{Cd}-\mathrm{O}$ bond lengths (2.439(4)-2.469(4) $\AA$ ) and $\mathrm{O}-\mathrm{Cd}-\mathrm{O}$ angles $\left(52.5(1), 53.0(1)^{\circ}\right.$ ) are comparable with analogues in the CSD $(2.413 \AA$, $\left.53.698^{\circ}\right)$.

\section{CONCLUSION}

In this work $\left[\mathrm{Cd}(\mathrm{L})\left(\mathrm{CH}_{3} \mathrm{COO}\right)_{2}\right] \cdot 2 \mathrm{H}_{2} \mathrm{O}(\mathbf{1})$ was synthesized from the reaction between cadmium acetate and $\mathrm{L}$, ( $N, N^{\prime}$-bis(2-pyridinecarboxalidene)-1,2-cyclohexanediamine) and its spectral (IR, Raman, ${ }^{1} \mathrm{H}$ NMR) and structural properties were investigated. Structural analysis of $\mathbf{1}$ exhibits distorted triangular dodecahedral geometry around the cadmium atom. A study of the CSD structures revealed that the cadmium atom has coordination numbers in range of 2-10. Difference between asymmetric $\left(v_{\mathrm{as}}\right)$ and symmetric ( $\left.v_{\mathrm{s}}\right)$ stretching in the IR spectrum of 1 is $83 \mathrm{~cm}^{-1}$ which confirms the acetate ion acts as a bidentate ligand. A survey about complexes of $\mathrm{L}$ revealed that this ligand has three coordination modes. The synthesis of new complexes with $\mathrm{L}$ is ongoing by our research group.

Acknowledgments. We are grateful to Payame Noor University of I. R. Iran for financial support. And the pub- 
lication cost of this paper was supported by the Korean Chemical Society.

\section{REFERENCES}

1. Jones, R. D.; Summer ville, D. A.; Basolo, F. Chem. Rev. 1979, 79, 139.

2. Dugas, H.; Penney, C. Bioorganic Chemistry; Springer: New York, U.S.A., 1981; p. 435.

3. Margerum, J. D.; Miller, L. J. Photochromism, Interscience; Wiley: New York, U.S.A., 1971; p. 569.

4. Henrici-Olive, G.; Olive, S. The Chemistry of the Catalyzed Hydrogenation of Carbon Monoxide; Springer: Berlin, Germany., 1984; p. 152.

5. Gupta, K. C.; Sutar, A. K. Coord. Chem. Rev. 2008, 252, 1420.

6. Gupta, K. C.; Sutar, A. K.; Lin, C. C. Coord. Chem. Rev. 2009, 253, 1926.

7. Sawodny, W. J.; Riederer, M. Angew. Chem. Int. Ed. 1977, $16,859$.

8. El-Sherif, A. A.; Eldebss, T. M. A. Spectrochim. Acta, Part A 2011, 79, 1803.

9. Etaiw, S. E. H.; Abd El-Aziz, D. M.; Abd El-Zaher, E. H.; Ali, E. A. Spectrochim. Acta, Part A 2011, 79, 1331.

10. Hakimi, M.; Moeini, K.; Mardani, Z.; Schuh, E.; Mohr, F. J. Coord. Chem. 2013, 66, 1129.

11. Lu, X. H.; Xia, Q. H.; Zhan, H. J.; Yuan, H. X.; Ye, C. P.; Su, K. E.; Xu, G. J. Mol. Catal. A: Chem. 2006, 250, 62.

12. Dolomanov, O. V.; Bourhis, L. J.; Gildea, R. J.; Howard, J. A. K.; Puschmann, H. J. Appl. Crystallogr. 2009, 42, 339.

13. Sheldrick, G. M. Acta Crystallogr., Sect. A 2008, 64, 112.

14. Schoumacker, S.; Hamelin, O.; Pecaut, J.; Fontecave, M. Inorg. Chem. 2003, 42, 8110.

15. Tsiouri, M.; Hadjiliadis, N.; Arslan, T.; Kariuki, B. M.; Plakatouras, J. C. Inorg. Chem. Commun. 2006, 9, 429.

16. Nguyen, Q. T.; Jeong, J. H. Polyhedron 2006, 25, 1787.

17. Kano, S.; Nakano, H.; Kojima, M.; Baba, N.; Nakajima, K. Inorg. Chim. Acta 2003, 349, 6.

18. Baar, C. R.; Jennings, M. C.; Puddephatt, R. J.; Muir, K.
W. Organometallics 1999, 18, 4373.

19. Morales, D.; Perez, J.; Riera, L.; Riera, V.; Corzo-Suarez, R.; Garcia-Granda, S.; Miguel, D. Organometallics 2002, $21,1540$.

20. van Stein, G. C.; van der Poel, H.; van Koten, G.; Spek, A. L.; Duisenberg, A. J. M.; Pregosin, P. S. Chem. Commun. 1980, 1016.

21. Baar, C. R.; Jennings, M. C.; Puddephatt, R. J. Organometallics 2001, 20, 3459.

22. Nakamoto, K. Infrared and Raman Spectra of Inorganic and Coordination Compounds, 6th ed; John Wiley \& Sons: Hoboken, U.S.A.; 2009; pp.228 and 232.

23. Hakimi, M.; Mardani, Z.; Moeini, K.; Mohr, F.; Schuh, S.; Vahedi, H. Z. Naturforsch. 2012, 67b, 452.

24. Hakimi, M.; Mardani, Z.; Moeini, K.; Fernandes, M. A. J. Coord. Chem. 2012, 65, 2221.

25. Hakimi, M.; Mardani, Z.; Moeini, K.; Minoura, M.; Raissi, H. Z. Naturforsch. 2011, 66b, 1122.

26. Hakimi, M.; Yazdanbakhsh, M.; Heravi, M. M.; Ghassemzadeh, M.; Neumüller, B. Z. Anorg. Allg. Chem. 2002, 628, 1899.

27. Farrugia, L. J. J. Appl. Crystallogr. 1997, 30, 565.

28. Macrae, C. F.; Bruno, I. J.; Chisholm, J. A.; Edgington, P. R.; McCabe, P.; Pidcock. E.; Rodriguez-Monge, L.; Taylor, R.; van de Streek, J.; Wood, P. A. J. Appl. Crystallogr. 2008, 41, 466.

29. Bergerhoff, G.; Berndt, M.; Brandenburg, K. J. Res. Natl. Inst. Stand. Technol. 1996, 101, 221.

30. Allen, F. H.; Kennard, O.; Watson, D. G.; Brammer, L.; Orpen, A. G. J. Chem. Soc. Perkin. Trans. II 1987, S1.

31. Vista, Program for the display and analysis of geometrical and numerical information retrieved from the CSD (version 2.1) Cambridge, U.K., 2011.

32. Hakimi, M.; Moeini, K.; Mardani, Z.; Fernandes, M. A.; Mohr, F.; Schuh, E. J. Coord. Chem. 2012, 65, 1232.

33. Hakimi, M.; Kukovec, B. M.; Rezvaninezhad, M.; Schuh, E.; Mohr, F. Z. Anorg. Allg. Chem. 2011, 637, 2157.

34. Desiraju, G. R.; Steiner, T. The Weak Hydrogen Bond, IUCr Monographs on Crystallography 9; Oxford University Press: Oxford, U.K., 1999; p.12. 